\title{
Lung function and CT lung densitometry in 37- to 39-year-old individuals with alpha-I-antitrypsin deficiency
}

This article was published in the following Dove Press journal: International Journal of COPD

\author{
Behrouz Mostafavi' \\ Sandra Diaz ${ }^{2}$ \\ Eeva Piitulainen' \\ Berend C Stoel ${ }^{3}$ \\ Per Wollmer ${ }^{4}$ \\ Hanan A Tanash' \\ 'Department of Respiratory Medicine \\ and Allergology Malmö, Skåne \\ University Hospital, Lund University, \\ Malmö, Sweden; ${ }^{2}$ Department of \\ Clinical Physiology Malmö, Skåne \\ University Hospital, Lund University, \\ Malmö, Sweden; ${ }^{3}$ Division of Image \\ Processing, Department of Radiology, \\ Leiden University Medical, Leiden, \\ the Netherlands; ${ }^{4}$ Department \\ of Translational Medicine, Lund \\ University, Malmö, Sweden
}

Background: Alpha-1-antitrypsin (AAT) deficiency is a hereditary disorder that predisposes to emphysema. A cohort of severe (PiZZ) and moderate (PiSZ) AAT-deficient newborn infants was identified by the Swedish national neonatal AAT screening program in 1972-1974 and has been followed-up since birth. Our aim was to study whether the cohort has signs of emphysema in pulmonary function tests (PFTs) and computed tomography (CT) densitometry at 38 years of age in comparison with an age-matched control group, randomly selected from the population registry. Methods: Forty-one PiZZ, 18 PiSZ, and 61 control subjects (PiMM) underwent complete PFTs, measurement of resistance and reactance in the respiratory system by impulse oscillometry (IOS)/forced oscillation technique (FOT), and CT densitometry. The results were related to self-reported smoking habits.

Results: The total lung capacity (TLC) \% of the predicted value was significantly higher in the PiZZ ever-smokers than in the PiZZ never-smokers $(P<0.05)$, PiSZ never-smokers $(P=0.01)$ and the PiMM never-smokers $(P=0.01)$. The residual volume $(\mathrm{RV}) \%$ of the predicted value was significantly higher in the PiZZ ever-smokers compared to the PiMM never-smokers $(P<0.01)$. The PiZZ ever-smokers had a significantly lower carbon monoxide transfer coefficient $(K c o)$ than the PiSZ never-smokers $(P<0.01)$ and PiMM never-smokers $(P<0.01)$. Respiratory system resistance at $5 \mathrm{~Hz}(P<0.01)$, at $20 \mathrm{~Hz}(P<0.01)$, and the area of low reactance (Alx; $P<0.05$ ) were significantly lower and respiratory system reactance at $5 \mathrm{~Hz}(P<0.05)$ was significantly higher in PiZZ subjects compared to the PiMM subjects. No statistically significant differences in the CT densitometry parameters were found between the Pi subgroups.

Conclusion: The physiological parameters in the PiZZ ever-smokers showed evidence of hyperinflation and emphysema before the age of 40 years.

Keywords: alpha-1-antitrypsin deficiency, lung function, lung disease, screening, impulse oscillometry

\section{Introduction}

Severe alpha-1-antitrypsin (AAT) deficiency (PiZZ) is a known risk factor for the development of lung emphysema and COPD. ${ }^{1,2}$ AAT is a $52-\mathrm{kDa}$ protein, a member of the SERPIN (SERine Protease INhibitor) family that inactivates serine proteases such as neutrophil elastase. AAT deficiency is an autosomal codominant hereditary disorder. $Z$ protein is associated with intracellular accumulation in the liver, decreased serum levels, and has shown chemotactic properties in vivo. S protein is not associated with intracellular accumulation and inhibits elastase normally. ${ }^{3-6} \mathrm{~S}$ protein is shown to be associated with exaggerated intracellular degradation of newly synthesized AAT in the liver, resulting in reduced secretion of AAT. ${ }^{?}$
Correspondence: Behrouz Mostafavi Department of Respiratory Medicine and Allergology, Skåne University Hospital, Lund University, Jan Waldenströms gata 24, plan 4, SUS Malmö,

S-205 02, Malmö, Sweden

Tel +46 40331000

Email behrouz.mostafavi@med.lu.se 
In clinical practice, COPD is diagnosed initially by the primary physician according to the Global Initiative for Chronic Obstructive Lung Disease (GOLD) criteria by compiling complete anamnestic information, including exposure, symptoms, smoking habits, and result of spirometry. For a more comprehensive diagnosis, complete pulmonary function tests (PFTs), including diffusing capacity for carbon monoxide, are employed. Impulse oscillometry (IOS)/ forced oscillation technique (FOT) is a noninvasive method for measuring airway resistance and reactance that can be performed during tidal breathing. IOS/FOT is reported to be a good complementary diagnostic tool for the management and monitoring of asthma and COPD. ${ }^{8-11}$ Computed tomography (CT) with $\mathrm{CT}$ densitometry is considered to be more accurate to assess the progression of emphysema than PFTs. ${ }^{12,13}$

AAT deficiency is most often diagnosed in patients who already have developed clinical signs of lung disease, before being identified as AAT deficient. The natural course and early signs of lung disease are still not fully understood. ${ }^{1,2}$ The detection of early signs of lung disease is crucial for treatments to inhibit the further development of the disease. ${ }^{14}$

The Swedish national neonatal AAT screening program was carried out in 1972-1974, when all 200,000 newborn children were screened for AAT deficiency. ${ }^{15}$ A cohort including 127 PiZZ, 2 PiZnull, 54 PiSZ, and 1 PiSnull children was identified. Five PiZZ children and one PiSZ child died before the age of 8 years. The cohort has been followed up regularly. During the follow-up, five new PiZZ individuals, born abroad during the screening period, have been identified and added to the cohort.

Our aim was to investigate signs of emphysema in this cohort at 38 years of age, in comparison with age-matched control subjects, randomly selected from the population registry, using PFT, IOS/FOT, and CT-densitometry as early detection tools.

\section{Methods}

\section{Study population}

One PiZZ and three PiSZ individuals had died before the present check-up. The remaining cohort, including 126 PiZZ, 2 PiZnull, 50 PiSZ, and 1 PiSnull individuals, was invited to participate in this follow-up study. A random sample of 300 age-matched individuals, randomly picked from the Swedish population registry, was invited as a control group.

The study was conducted in accordance with the Helsinki Declaration and approved by the Regional Ethical Review
Board of Lund, Sweden. All study participants gave their signed informed consent.

\section{Questionnaire}

All participants visited the Department of Respiratory Medicine, Skåne University Hospital Malmö, Sweden and completed a questionnaire on smoking habits and symptoms. (Figure S1) The study participants reported whether they had ever smoked. If yes, the date when they began and stopped smoking, if applicable, and the average number of cigarettes per day during the period of smoking were reported in the questionnaire. A smoker was defined as a person who had smoked one cigarette or more per day for at least 1 year.

\section{PFT}

Complete PFT were performed with the same equipment and by an experienced technician at the Department of Clinical Physiology, Skåne University Hospital Malmö. The PFT was performed after administration of $1.0 \mathrm{mg}$ inhaled terbutaline. The functions measured by the PFT included forced expiratory volume in 1 second $\left(\mathrm{FEV}_{1}\right)$, vital capacity (VC), total lung capacity (TLC), functional residual capacity (FRC), residual volume (RV), diffusing capacity for carbon monoxide $\left(\mathrm{D}_{\mathrm{L}, \mathrm{CO}}\right)$, and alveolar volume (VA). The carbon monoxide transfer coefficient (Kco) was calculated. FRC, TLC, and RV were measured with body plethysmography. In addition, the RV/TLC ratio and FRC/TLC ratio were calculated as indicators of hyperinflation. The PFT, including the calibration of the equipment, was performed according to the guidelines of the American Thoracic Society/European Respiratory Society. ${ }^{16,17}$ The PFT results are reported as the percentage of the predicted values, according to the European Coal and Steel Community reference values. ${ }^{18} \mathrm{The} \mathrm{FEV}_{1} / \mathrm{VC}$ ratios are also expressed as absolute values.

\section{IOS/FOT}

IOS/FOT was performed directly after the complete PFT examination, with the same equipment and by the same technicians at the Department of Clinical Physiology, Skåne University Hospital Malmö. IOS (MasterScreen IOS; Jaeger, Hoechbery, Germany) with a broad-frequency wave of $5-35 \mathrm{~Hz}$ and a pulse generation interval of 0.2 seconds was employed. Respiratory system resistance at $5 \mathrm{~Hz}$ $(\mathrm{R} 5 \mathrm{~Hz})(\mathrm{kPa} /(\mathrm{L} / \mathrm{s}))$ and $20 \mathrm{~Hz}(\mathrm{R} 20 \mathrm{~Hz})(\mathrm{kPa} /(\mathrm{L} / \mathrm{s}))$, the resistance in the small airways $(\mathrm{R} 5 \mathrm{~Hz}-\mathrm{R} 20 \mathrm{~Hz})(\mathrm{kPa} /(\mathrm{L} / \mathrm{s}))$, respiratory system reactance at $5 \mathrm{~Hz}(\mathrm{X} 5 \mathrm{~Hz})(\mathrm{kPa} /(\mathrm{L} / \mathrm{s}))$, 
resonant frequency (Fres) $(\mathrm{Hz})$, and the area of low reactance $(\mathrm{Alx})(\mathrm{kPa} / \mathrm{L})$ were measured. ${ }^{8-10,19}$

\section{CT densitometry}

The CT examinations were performed at the Department of Radiology, University Hospital in Malmö, using a Siemens Somatom Sensation $64^{\circledR}$ (Erlangen, Germany) multidetector scanner at full inspiration (ie, at TLC) after three deep inhalation maneuvers, using the helical technique and acquisition in the caudal-cranial direction to avoid breathing artifacts at the level of the diaphragm. The images were processed with Pulmo-CMS ${ }^{\circledR}$ software (Medis Specials, Leiden, the Netherlands). The same method was used as at the previously published check-ups of the cohort. ${ }^{20}$ The 15 th percentile density $\left(\mathrm{PD}_{15}\right)$ was calculated as a measure of lung density. $\mathrm{PD}_{15}$ is expressed as $\mathrm{g} / \mathrm{L}$ by adding 1,000 to the $\mathrm{HU}$ values. In addition, the relative area below $-910 \mathrm{HU}\left(\mathrm{RA}_{-910}\right)$ was calculated. Lung volume was determined by summing the volumes of all voxels within the lungs and accounting for overlap between slices. Heterogeneity was calculated as a measure of variation in percentile density between the different vertical partitions. ${ }^{21}$ The CT densitometry was performed after inhalation of $1.0 \mathrm{mg}$ of terbutaline. An experienced radiologist (SD) processed all the CT images. She was blinded to all clinical data and to the Pi phenotype of the subjects.

\section{Statistical analysis}

The Statistical Package for the Social Sciences (SPSS 22.0) software was employed for performing the statistical analysis. The continuous variables were analyzed by ANOVA, and the Tukey's honest significant difference test was used for multiple comparisons. Categorical values were analyzed by chi-squared test. A $P$-value of $<0.05$ was considered significant.

\section{Results \\ Study participants}

Table 1 presents the demographic data of the study participants. The proportion of men was higher among the AAT-deficient subjects than among the controls, but the difference was not statistically significant. Current smoking was less frequent in the cohort than in the control group, but the difference was not statistically significant.

\section{PFT and IOS}

The results of PFT and IOS in the Pi subgroups are reported in Table 2. The PiZZ subjects had significantly higher RV than the PiMM subjects $(P<0.01)$ and lower Kco than the PiSZ subjects $(P<0.01)$. They also had lower Kco than the PiMM subjects but the difference was not statistically significant. The RV/TLC ratio $(P<0.05)$ and RV/TLC \% of predicted $(P<0.05)$ were significantly higher in the PiZZ subjects compared with the PiMM subjects. The FRC/TLC ratio was significantly higher in the PiZZ than in the PiSZ subjects $(P<0.05)$. The mean Alx $(P<0.05), \mathrm{R} 5 \mathrm{~Hz}(P<0.01), \mathrm{R} 20 \mathrm{~Hz}$ $(P<0.01)$ were significantly lower while $\mathrm{X} 5 \mathrm{~Hz}(P<0.05)$ was significantly higher in the PiZZ group than in the PiMM group (Table 2).

The results of PFT in the smoking subgroups are shown in Table 3. Because only two PiZZ current smokers participated in the study, the results of the PFT were compared between the ever- and never-smokers. Because only two PiSZ subjects were former smokers and none was a current smoker, they were excluded from the statistical analysis. The PiZZ ever-smokers had significantly higher TLC than the PiZZ never-smokers $(P<0.05)$, the PiSZ never-smokers $(P<0.01)$ and the PiMM never-smokers $(P=0.01)$. They also had significantly higher RV $(P<0.01)$ (Figure 1$)$, RV/TLC ratios $(P=0.01)$, and $\mathrm{RV} / \mathrm{TLC} \%$ of predicted $(P=0.01)$ than the PiMM never-smokers. FRC was significantly

Table I Clinical characteristics of the study participants

\begin{tabular}{|l|l|l|l|}
\hline Pi phenotype & PiZZ (n=4l) & PiSZ (n=18) & PiMM (n=6 I) \\
\hline Gender: men, n (\%) & 2I (5I\%) & II (6I\%) & $22(36 \%)$ \\
\hline Age (years), mean (range) & $38.4(37.0-39.0)$ & $38.3(38.0-39.0)$ & $38.0(37.0-39.0)$ \\
\hline BMl, ${ }^{2}$ mean (range) & $25(19-42)$ & $27(22-32)$ & $26(19-38)$ \\
\hline Smoking habits & & & \\
\hline Never, n (\%) & $30(73 \%)$ & $16(89 \%)$ & $43(71 \%)$ \\
\hline Former, n (\%) & $9(22 \%)$ & $2(11 \%)$ & $10(16 \%)$ \\
\hline Current, n (\%) & $2(5 \%)$ & 0 & $8(13 \%)$ \\
\hline Pack-years, ever-smokers mean (range) & $9.2(2.3-20)$ & $1.9(0.3-3.5)$ & $11.8(I .0-25.0)$ \\
\hline
\end{tabular}

Note: ${ }^{\mathrm{B} M \mathrm{Ml}}$ (body mass index) $=$ weight $(\mathrm{kg}) /$ height $^{2}(\mathrm{~m})$.

Abbreviation: $\mathrm{Pi}$, protease inhibitor. 
Table 2 Results of the pulmonary function tests (PFT), diffusing capacity, and impulse oscillometry (IOS) in the Pi subgroups

\begin{tabular}{|c|c|c|c|}
\hline Pi phenotype & $\begin{array}{l}\text { PiZZ }(n=4 I) \\
\text { Mean }(95 \% \mathrm{Cl})\end{array}$ & $\begin{array}{l}\text { PiSZ }(n=18) \\
\text { Mean }(95 \% \mathrm{Cl})\end{array}$ & $\begin{array}{l}\text { PiMM }(n=6 \mathrm{I}) \\
\text { Mean }(95 \% \mathrm{Cl})\end{array}$ \\
\hline \multicolumn{4}{|l|}{ PFT } \\
\hline FEV, \% pred. & $104(99-106)$ & $104(98-110)$ & $108(105-111)$ \\
\hline VC $\%$ pred. & $116(112-120)$ & $114(107-121)$ & $117(114-120)$ \\
\hline $\mathrm{FEV}_{1} / \mathrm{VC}$ ratio & $76(72-79)$ & $77(74-80)$ & $78(77-80)$ \\
\hline $\mathrm{FEV}_{1} / \mathrm{VC} \%$ pred. & $94(90-98)$ & $95(92-99)$ & $96(95-98)$ \\
\hline TLC \% pred. & II4 (I09-II8) & $109(102-116)$ & $110(108-113)$ \\
\hline RV \% pred. & $118(109-126)^{\mathrm{a}}$ & $107(98-117)$ & $103(100-106)$ \\
\hline $\mathrm{RV} / \mathrm{TLC}$ ratio & $30(28-31)^{b}$ & $28(26-30)$ & $28(27-28)$ \\
\hline RV/TLC \% pred. & $93(88-97)^{c}$ & $87(82-92)$ & 87 (84-89) \\
\hline FRC \% of pred. & $130(\mid 17-143)$ & $116(101-131)$ & $117(110-123)$ \\
\hline $\mathrm{FRC/TLC}$ ratio & $49(47-50)^{d}$ & $44(40-48)$ & $46(44-48)$ \\
\hline FRC/TLC \% pred. & $75(68-83)$ & $65(51-78)$ & $76(70-83)$ \\
\hline \multicolumn{4}{|l|}{ Diffusing capacity } \\
\hline $\mathrm{D}_{\mathrm{L}, \mathrm{CO}} \%$ pred. & $92(88-96)$ & $98(9 \mid-106)$ & 95 (93-98) \\
\hline Kco \% pred. & $92(88-96)^{\mathrm{e}}$ & $102(95-109)$ & $97(94-100)$ \\
\hline \multicolumn{4}{|l|}{ Impulse oscillometry } \\
\hline $\mathrm{R} 5 \mathrm{~Hz} \mathrm{kPa}(\mathrm{L} / \mathrm{s})$ & $0.26(0.25-0.28)^{f}$ & $0.28(0.25-0.3 \mathrm{I})$ & $0.30(0.29-0.32)$ \\
\hline $\mathrm{R} 20 \mathrm{~Hz} \mathrm{kPa}(\mathrm{L} / \mathrm{s})$ & $0.25(0.23-0.26)^{g}$ & $0.26(0.23-0.28)$ & $0.28(0.27-0.30)$ \\
\hline $\mathrm{R} 5 \mathrm{~Hz}-\mathrm{R} 20 \mathrm{~Hz} \mathrm{kPa}(\mathrm{L} / \mathrm{s})$ & $0.017(0.01-0.03)$ & $0.02(0.01-0.04)$ & $0.02(0.01-0.03)$ \\
\hline $\mathrm{X} 5 \mathrm{~Hz} \mathrm{kPa}(\mathrm{L} / \mathrm{s})$ & $-0.06(-0.07 \text { to }-0.05)^{\mathrm{h}}$ & $-0.07(-0.08$ to -0.05$)$ & $-0.08(-0.09$ to -0.07$)$ \\
\hline Fres $\mathrm{Hz}$ & $8.8(8.1-9.5)$ & $8.7(7.2-10.1)$ & $9.4(8.8-10.0)$ \\
\hline Alx kPa/L & $0.13(0.09-0.17)^{i}$ & $0.15(0.09-0.20)$ & $0.21(0.16-0.25)$ \\
\hline
\end{tabular}

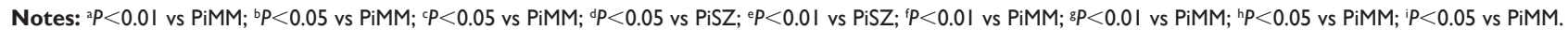
Abbreviations: $\mathrm{Alx}$, area of low reactance; $\mathrm{D}_{\mathrm{L}, \mathrm{CO}}$, diffusing capacity for carbon monoxide; $\mathrm{FEV} \mathrm{V}_{1}$, forced expiratory volume in I second; $\mathrm{FRC}$, functional residual capacity; Fres, resonant frequency; Kco, carbon monoxide transfer coefficient; Pi, protease inhibitor; $\mathrm{R} 5 \mathrm{~Hz}$, respiratory system resistance at $5 \mathrm{~Hz}$; $\mathrm{R} 2 \mathrm{OHz}$, respiratory system resistance at $20 \mathrm{~Hz}$; RV, residual volume; TLC, total lung capacity; VC, vital capacity; X5Hz, respiratory system reactance at $5 \mathrm{~Hz}$.

higher in the PiZZ ever-smokers than in the PiZZ neversmokers $(P<0.05)$, PiSZ never-smokers $(P=0.01)$, PiMM ever-smokers ( $P=0.01)$, and PiMM never-smokers $(P=0.01)$. The PiZZ ever-smokers had a significantly higher FRC/TLC ratio than the PiSZ never-smokers $(P<0.05)$ and significantly lower $K$ co than the PiSZ never-smokers $(P<0.01)$ and the PiMM never-smokers $(P<0.01)$ (Figure 2 and Table 3 ).

Two PiZZ ever-smokers $(18 \%)$ and none in the other smoking subgroups had $\mathrm{FEV}_{1}<80 \%$ of the predicted value (NS). Four PiZZ never-smokers (13\%), three PiZZ eversmokers (27\%), four PiMM never-smokers (13\%), and two PiMM ever-smokers (11\%) had a $\mathrm{FEV}_{1} / \mathrm{VC}$ ratio $<0.7$ (NS).

The mean resistance and reactance did not reveal any statistically significant differences among the smoking subgroups (data not shown).

\section{CT densitometry}

The results of CT densitometry are shown in Tables 4 and 5 . The PiZZ ever-smokers had lower mean apical $\mathrm{PD}_{15}$ and higher mean apical $\mathrm{RA}_{-910}$ than the PiZZ never-smokers, PiSZ never-smokers and both PiMM smoking subgroups, but the differences were not statistically significant. Fourteen (47\%) PiZZ never-smokers, 8 (73\%) PiZZ ever-smokers, 15 (35\%) PiMM never-smokers, and 7 (39\%) PiMM eversmokers had whole $\mathrm{PD}_{15}(\mathrm{~g} / \mathrm{L})$ below the lower limit of the 95\% CI (NS). Eleven (37\%) PiZZ never-smokers, 8 (73\%) PiZZ ever-smokers, 13 (30\%) PiMM never-smokers, and 7 (39\%) PiMM ever-smokers had the whole RA-910 above the upper limit of the $95 \%$ CI (NS).

The mean heterogeneity was higher in the PiZZ subjects than other Pi subgroups but the differences were not statistically significant. No signs of emphysema were detected by the visual assessment of the $\mathrm{CT}$ images.

\section{The PiZZ current smokers}

Two PiZZ current smokers participated in the study, both female. The results of their lung function tests and CT densitometry are shown in Table 6 . Both of them had manifest 
Table 3 Results of the pulmonary function tests (PFT) and diffusing capacity in the ever- and never-smoking Pi subgroups

\begin{tabular}{|c|c|c|c|c|c|}
\hline \multirow{2}{*}{$\begin{array}{l}\text { Pi phenotype } \\
\text { Smoking groups }\end{array}$} & \multicolumn{2}{|l|}{ PizZ } & \multirow{2}{*}{$\begin{array}{l}\text { PiSZ } \\
\text { Never-smokers } \\
(\mathrm{n}=16) \\
\text { Mean }(95 \% \mathrm{Cl})\end{array}$} & \multicolumn{2}{|l|}{ PiMM } \\
\hline & $\begin{array}{l}\text { Never-smokers } \\
(n=30) \\
\text { Mean }(95 \% \mathrm{Cl})\end{array}$ & $\begin{array}{l}\text { Ever-smokers } \\
(n=I I) \\
\text { Mean }(95 \% \mathrm{Cl})\end{array}$ & & $\begin{array}{l}\text { Never-smokers } \\
(n=43) \\
\text { Mean }(95 \% \mathrm{Cl})\end{array}$ & $\begin{array}{l}\text { Ever-smokers } \\
(\mathrm{n}=18) \\
\text { Mean }(95 \% \mathrm{Cl})\end{array}$ \\
\hline \multicolumn{6}{|l|}{ PFT } \\
\hline FEV, \% pred. & $106(101-110)$ & $99(83-115)$ & $102(96-109)$ & $108(105-112)$ & $107(100-113)$ \\
\hline VC \% pred. & $113(109-118)$ & $122(113-130)$ & 112 (I05-II9) & $116(113-120)$ & $118(111-125)$ \\
\hline $\mathrm{FEV}_{\mathrm{I}} / \mathrm{VC} \%$ pred. & 97 (94-99) & $85(72-98)$ & 95 (91-98) & 97 (95-99) & 95 (91-99) \\
\hline $\mathrm{FEV}_{1} / \mathrm{NC}$ ratio & $78(76-8 I)$ & $69(59-80)$ & 77 (74-80) & $79(78-80)$ & 77 (74-8I) \\
\hline TLC \% pred. & $110(106-114)$ & $123(112-134)^{\mathrm{a}}$ & $108(101-115)$ & $109(106-112)$ & II3 (107-I I8) \\
\hline RV \% pred. & $112(106-118)$ & $133(103-163)^{\mathrm{b}}$ & 107 (96-II7) & 101 (97-105) & $107(101-113)$ \\
\hline RV/TLC ratio & $29(28-30)$ & $32(27-37)^{c}$ & $28(26-30)$ & $27(26-28)$ & $28(27-30)$ \\
\hline RV/TLC \% pred. & $90(86-94)$ & $99(82-116)^{d}$ & 87 (8I-93) & $86(83-89)$ & $89(84-94)$ \\
\hline FRC \% pred. & $121(112-130)$ & $154(111-198)^{e}$ & $112(97-128)$ & $118(110-126)$ & $113(102-124)$ \\
\hline $\mathrm{FRC/TLC}$ ratio & $48(46-50)$ & $51(48-55)^{f}$ & $43(38-47)$ & $46(43-48)$ & $46(42-50)$ \\
\hline FRC/TLC \% pred. & 70 (62-79) & $89(73-105)^{g}$ & 61 (47-75) & $76(68-84)$ & $78(65-91)$ \\
\hline \multicolumn{6}{|l|}{ Diffusing capacity } \\
\hline $\mathrm{D}_{\mathrm{L}, \mathrm{co}} \%$ pred. & 93 (89-97) & $89(78-100)$ & $98(90-105)$ & $96(93-99)$ & 93 (87-99) \\
\hline Kco \% pred. & 94 (91-98) & $85(73-96)^{\mathrm{h}}$ & $103(95-111)$ & $99(96-103)$ & $92(86-97)$ \\
\hline
\end{tabular}

Notes: a $P<0.05$ vs PiZZ never-smokers, $P<0.01$ vs PiSZ never-smokers, $P=0.01$ vs $P$ iMM never-smokers; ${ }^{b} P<0.01$ vs $P$ iMM never-smokers; ${ }^{c} P=0.01$ vs $P i M M$ never-smokers;

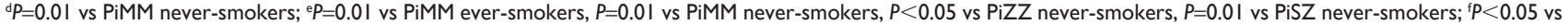
PiSZ never-smokers; ${ }^{8} P<0.05$ vs PiSZ never-smokers; ${ }^{h} P<0.01$ vs $P i M M$ never-smokers, $P<0.01$ vs PiSZ never-smokers.

Abbreviations: $\mathrm{D}_{\mathrm{L}, \mathrm{CO}}$, diffusing capacity for carbon monoxide; $\mathrm{FEV}_{1}$, forced expiratory volume in I second; FRC, functional residual capacity; Kco, carbon monoxide transfer coefficient; Pi, protease inhibitor; RV, residual volume; TLC, total lung capacity; VC, vital capacity.

COPD, GOLD stadium II with $\mathrm{FEV}_{1} / \mathrm{VC}$ ratios below 0.70 , high RV, FRC, FRC/RV ratios, and decreased $\mathrm{FEV}_{1}, \mathrm{Kco}$, and $\mathrm{D}_{\mathrm{L}, \mathrm{CO}}$. They had low $\mathrm{PD}_{15}$ and high $\mathrm{RA}_{-910}$. None of them had emphysema as assessed visually on CT images. None of the PiMM current smokers had $\mathrm{FEV}_{1} / \mathrm{VC}$ ratios below 0.70 .

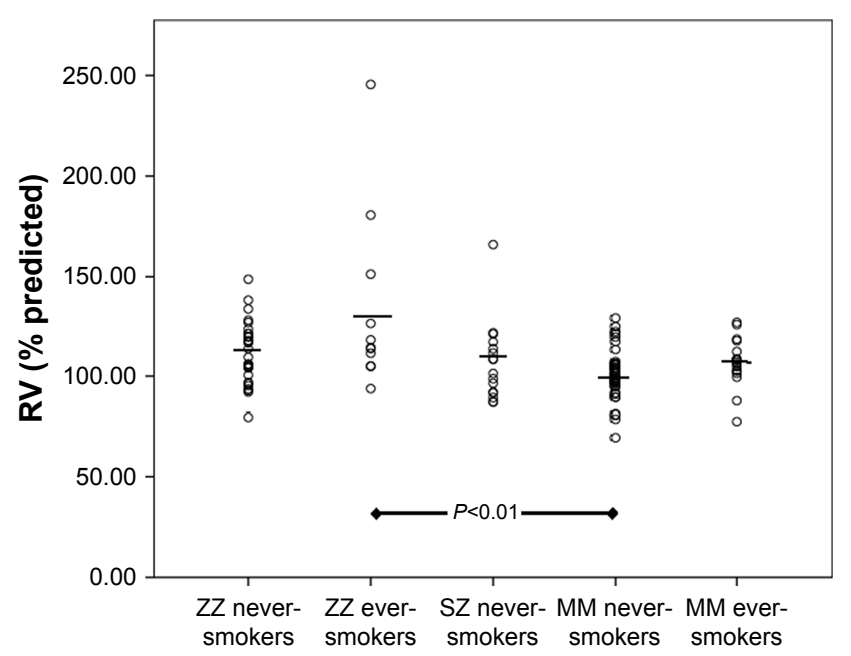

Figure I The RV \% predicted in Pi-smoking categories.

Note: The means are indicated by horizontal bars.

Abbreviations: $\mathrm{Pi}$, protease inhibitor; RV, residual volume.

\section{Discussion}

This follow-up, case-control study of AAT-deficient subjects, identified by neonatal screening, shows that ever-smoking PiZZ individuals have, before the age of 40, physiological changes indicating early signs of emphysema. Furthermore, the two PiZZ current smokers had manifest

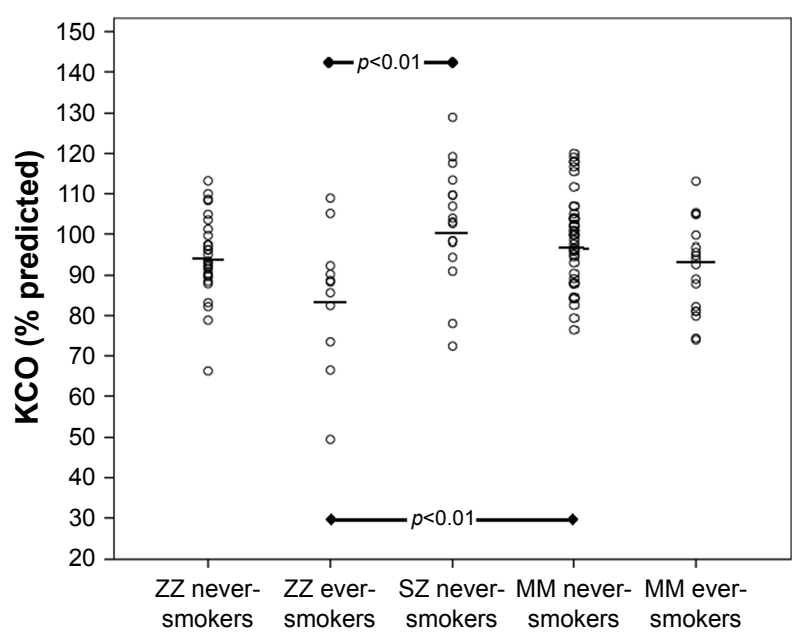

Figure 2 The $\mathrm{Kco} \%$ predicted in the Pi-smoking categories.

Note: The means are indicated by horizontal bars.

Abbreviations: $\mathrm{Pi}$, protease inhibitor; $\mathrm{Kco}$, carbon monoxide transfer coefficient. 
Table 4 Results of computed tomography (CT) densitometry in the Pi subgroups, independent of smoking categories

\begin{tabular}{|c|c|c|c|}
\hline Pi phenotype & $\begin{array}{l}\text { PiZZ }(n=4 I) \\
\text { Mean }(95 \% \mathrm{Cl})\end{array}$ & $\begin{array}{l}\text { PiSZ }(n=15) \\
\text { Mean }(95 \% \mathrm{Cl})\end{array}$ & $\begin{array}{l}\operatorname{PiMM}(n=48) \\
\text { Mean }(95 \% \mathrm{Cl})\end{array}$ \\
\hline Heterogeneity & $5.1(3.6-6.7)$ & $3.2(2.4-4.0)$ & $3.4(3.0-3.8)$ \\
\hline Whole RA ${ }_{-910}$ & $27(2 \mathrm{I}-33)$ & $30(22-32)$ & $23(19-28)$ \\
\hline Whole $\mathrm{PD}_{15}(\mathrm{~g} / \mathrm{L})$ & $82(75-89)$ & 79 (70-88) & 89 (82-95) \\
\hline Apical RA ${ }_{-910}$ & 78 (7I-86) & 77 (67-87) & $86(80-93)$ \\
\hline Apical $\mathrm{PD}_{15}(\mathrm{~g} / \mathrm{L})$ & $31(25-38)$ & $34(24-44)$ & $26(2|-3|)$ \\
\hline Basal RA ${ }_{-910}$ & $25(\mid 9-31)$ & $29(2 \mathrm{I}-37)$ & 23 (I8-29) \\
\hline Basal $\mathrm{PD}_{15}(\mathrm{~g} / \mathrm{L})$ & 85 (78-92) & $80(72-88)$ & 89 (83-96) \\
\hline
\end{tabular}

Abbreviations: $\mathrm{PD}_{15}$, 15 th percentile density; $\mathrm{Pi}$, protease inhibitor; $\mathrm{RA}_{-91}$, relative area below $-910 \mathrm{HU}$.

COPD with an $\mathrm{FEV}_{1} / \mathrm{VC}$ ratio $<0.70$, high $\mathrm{RVs}$, and low $K$ co (Table 6). These results are in accordance with our recently published results on symptoms and dynamic spirometry in this cohort. ${ }^{22}$

AAT deficiency has a quite broad clinical and disease spectrum. Our previously published study from the Swedish AATD Registry has also shown that many never-smoking PiZZ individuals, identified by screening, have normal life expectancy compared with the Swedish general population. ${ }^{23}$ Thus, individuals with severe AAT deficiency may live a healthy life without any clinical manifestations of disease. Factors such as smoking are the major risk for the development of emphysema. ${ }^{24}$

This cohort has been followed-up since birth. We have chosen the frequency of check-ups of 4 years in adulthood because of the well-preserved health status of the members of the cohort. With a longer interval, there would be a risk of loosening the contact with the subjects, and a shorter interval would not reveal any clinically relevant changes between the check-ups.
At the 30-year follow-up, only two PiZZ ever-smokers (one PiZZ current smoker) participated in the study; both shown signs of COPD. ${ }^{25}$ At the 34-year follow-up, the PiZZ ever-smokers had significantly lower $K$ co in comparison to the PiSZ and PiMM never-smokers. ${ }^{20}$

IOS showed lower resistance at $5 \mathrm{~Hz}$ and $20 \mathrm{~Hz}$ in the PiZZ subjects than in the PiMM subjects. Also reactance at $5 \mathrm{~Hz}$ was higher (less negative) and Fres lower in the PiZZ group than in the PiMM group (Table 2). These findings are contrary to what is usually seen in subjects with smokinginduced COPD compared with normal subjects. There may be differences in the pathogenesis between smoking-induced COPD and subjects with AAT deficiency. Whereas there is little doubt that smoking-induced COPD starts in the terminal bronchioles, ${ }^{26}$ emphysema may be more predominant at an early stage in subjects with AAT deficiency. The PiZZ subjects in this study showed evidence of hyperinflation (high FRC/TLC ratios) and air trapping (high RV/TLC ratios), which may offer an explanation for our findings. $\mathrm{R} 5 \mathrm{~Hz}$ is generally considered to represent resistance of the

Table 5 Results of the computed tomography (CT) densitometry in ever- and never-smoking Pi subgroups. Means and $95 \% \mathrm{Cl}$ are shown

\begin{tabular}{|c|c|c|c|c|c|}
\hline \multirow[t]{2}{*}{ Pi phenotype } & \multicolumn{2}{|l|}{ PizZ } & \multirow{2}{*}{$\begin{array}{l}\text { PiSZ } \\
\text { Never-smokers } \\
(n=15) \\
\text { Mean }(95 \% \mathrm{Cl})\end{array}$} & \multicolumn{2}{|l|}{ PiMM } \\
\hline & $\begin{array}{l}\text { Never-smokers } \\
(n=30) \\
\text { Mean }(95 \% \mathrm{Cl})\end{array}$ & $\begin{array}{l}\text { Ever-smokers } \\
(n=I I) \\
\text { Mean }(95 \% \mathrm{Cl})\end{array}$ & & $\begin{array}{l}\text { Never-smokers } \\
(n=32) \\
\text { Mean }(95 \% \mathrm{Cl})\end{array}$ & $\begin{array}{l}\text { Ever-smokers } \\
(\mathrm{n}=16) \\
\text { Mean }(95 \% \mathrm{Cl})\end{array}$ \\
\hline Heterogeneity & $4.1(3.3-4.8)$ & $8.0(2.1-13.8)$ & $3.2(2.4-4.0)$ & $3.5(2.9-4.1)$ & $3.3(2.8-3.7)$ \\
\hline Whole RA ${ }_{-910}$ & $25(|9-3|)$ & $33(18-47)$ & $30(22-38)$ & $25(|8-3|)$ & $21(13-28)$ \\
\hline Whole $\mathrm{PD}_{15}(\mathrm{~g} / \mathrm{L})$ & $83(77-90)$ & 78 (57-99) & 79 (70-88) & 87 (79-95) & $92(79-105)$ \\
\hline Apical RA ${ }_{-910}$ & $30(21-35)$ & $4 I(22-59)$ & $34(24-44)$ & $27(2 \mathrm{I}-34)$ & $24(15-32)$ \\
\hline Apical $\mathrm{PD}_{15}(\mathrm{~g} / \mathrm{L})$ & 81 (74-87) & $72(49-95)$ & $77(67-87)$ & 85 (77-92) & $90(77-103)$ \\
\hline Basal RA ${ }_{-910}$ & $24(|8-3|)$ & $27(|3-4|)$ & $29(21-37)$ & $25(18-32)$ & $21(13-28)$ \\
\hline Basal $\mathrm{PD}_{15}(\mathrm{~g} / \mathrm{L})$ & $84(77-91)$ & $88(68-108)$ & $80(72-88)$ & $88(80-96)$ & $92(80-105)$ \\
\hline
\end{tabular}

Abbreviations: $\mathrm{PD}_{15}$, 15 th percentile density; Pi, protease inhibitor; $\mathrm{RA}_{-910}$, relative area below -910 HU. 
Table 6 Results of the pulmonary function tests (PFT), diffusing capacity, impulse oscillometry (IOS), and computed tomography (CT) densitometry in the only two PiZZ current smokers, both female

\begin{tabular}{|c|c|c|}
\hline Pi phenotype & $\begin{array}{l}\text { PiZZ } \\
\text { Current } \\
\text { smoker I }\end{array}$ & $\begin{array}{l}\text { PiZZ } \\
\text { Current } \\
\text { smoker } 2\end{array}$ \\
\hline Age (years) & 39 & 37 \\
\hline Smoking, pack-years (n) & 12 & 8 \\
\hline $\mathrm{FEV}_{1} \%$ pred. & 64 & 51 \\
\hline VC \% pred. & 109 & 123 \\
\hline $\mathrm{FEV}_{1} / \mathrm{NC}$ ratio & 51 & 36 \\
\hline $\mathrm{FEV}_{\mathrm{I}} / \mathrm{NC} \%$ pred. & 62 & 44 \\
\hline TLC \% pred. & 152 & 142 \\
\hline RV \% pred. & 245 & 180 \\
\hline RV/TLC ratio & 50 & 39 \\
\hline RV/TLC \% pred. & 156 & 125 \\
\hline FRC \% pred. & 340 & 157 \\
\hline FRC/TLC ratio & 55 & 52 \\
\hline FRC/TLC \% pred. & 107 & 102 \\
\hline $\mathrm{D}_{\mathrm{L}, \mathrm{CO}} \%$ pred. & 72 & 57 \\
\hline Kco \% pred. & 66 & 50 \\
\hline $\mathrm{R} 5 \mathrm{~Hz} \mathrm{kPa}(\mathrm{L} / \mathrm{s})$ & 0.30 & 0.37 \\
\hline $\mathrm{R} 2 \mathrm{OHz} \mathrm{kPa}(\mathrm{L} / \mathrm{s})$ & 0.24 & 0.29 \\
\hline $\mathrm{R} 5 \mathrm{~Hz}-\mathrm{R} 2 \mathrm{OHz} \mathrm{kPa}(\mathrm{L} / \mathrm{s})$ & 0.06 & 0.08 \\
\hline $\mathrm{X} 5 \mathrm{~Hz} \mathrm{kPa}(\mathrm{L} / \mathrm{s})$ & -0.10 & -0.12 \\
\hline Fres $\mathrm{Hz}$ & 11.8 & 16.3 \\
\hline $\mathrm{Alx} \mathrm{kPa/L}$ & 0.27 & 0.55 \\
\hline Heterogeneity & 8.6 & 26.8 \\
\hline Whole $\mathrm{RA}_{-910}$ & 61.2 & 33.1 \\
\hline Whole $\mathrm{PD}_{15}(\mathrm{~g} / \mathrm{L})$ & 44 & 64 \\
\hline
\end{tabular}

Abbreviations: Alx, area of low reactance; $D_{L c o}$, diffusing capacity for carbon monoxide; $\mathrm{FEV}_{1}$, forced expiratory volume in I second; FRC, functional residua capacity; Fres, resonant frequency; Kco, carbon monoxide transfer coefficient; $\mathrm{PD}_{15}$ I5th percentile density; Pi, protease inhibitor; $\mathrm{RA}_{-910}$, relative area below $-910 \mathrm{HU}$; $\mathrm{R} 5 \mathrm{~Hz}$, respiratory system resistance at $5 \mathrm{~Hz} ; \mathrm{R} 2 \mathrm{OHz}$, respiratory system resistance at $20 \mathrm{~Hz}$; RV, residual volume; TLC, total lung capacity; VC, vital capacity; $X 5 \mathrm{~Hz}$. respiratory system reactance at $5 \mathrm{~Hz}$.

entire bronchial tree and $\mathrm{R} 20 \mathrm{~Hz}$ the resistance of "central airways". The difference in resistance between $5 \mathrm{~Hz}$ and $20 \mathrm{~Hz}$ is therefore often taken to represent "peripheral airways". It is not, however, precisely known which airway generations are measured. If the tethering forces on small airways are reduced in PiZZ subjects, this may be compensated for by hyperinflation. This would affect the dimensions not only of the small but also of more proximal airways that might contribute more to the result of the IOS measurements of resistance and reactance. The IOS measurements are performed during tidal breathing, and the findings are compatible with a higher degree of inflation during the measurement in the subjects with AAT deficiency than in the control group. However, the results did not differ significantly between the smoking subgroups, which may be due to the low number of ever-smokers, making it difficult to reach statistical significance.

In contrast to the results of PFTs, no statistically significant differences were found in the CT-densitometry parameters between the AAT-deficient and the control subjects, and none of the study participants had emphysema as judged by visual assessment of the CT images. At the 30 year follow-up, the only PiZZ current smoker participating had the lowest $\mathrm{PD}_{15}$ (60 g/L). ${ }^{25}$ At the 34-35 year follow-up, the PiZZ ever-smokers had significantly lower $\mathrm{PD}_{15}$ than the PiMM ever-smokers. ${ }^{20}$ In the present study, the two PiZZ current smokers also had low $\mathrm{PD}_{15}, 44 \mathrm{~g} / \mathrm{L}$ and $64 \mathrm{~g} / \mathrm{L}$, respectively (Table 6 ).

CT densitometry is considered to be an accurate and reliable method for the detection of emphysema, and it is considered to be a more accurate method than PFTs in detecting the progression of the emphysema. ${ }^{21}$ However, the previously published studies have mostly been based on patients who had already been diagnosed with COPD. In our study, we examined young AAT-deficient individuals for the detection of early signs of diffuse emphysema propagation. It is possible that complete PFTs including diffusing capacity and airways resistance and reactance measurements are more sensitive in detecting early, incipient emphysema, and hyperinflation than $\mathrm{CT}$ densitometry.

\section{Limitations}

The most important limitation of this study is the small number of participants among the AAT-deficient subjects. The most common reason was shortage of time, and second reason was long traveling distance.

\section{Conclusion}

At 37-39 years of age, the PiZZ ever-smokers, and especially current smokers, have evidence of emphysema. In contrast, the PiZZ and PiSZ never-smokers have normal lung function and no signs of emphysema. These results emphasize the importance of early diagnosis of AAT deficiency for prevention of smoking.

\section{Acknowledgments}

The authors wish to thank Ewa Ringdal Szemberg, Isabella Björk, and Helene Johansson Kvist for technical and secretarial support. The study was supported by unrestricted grants from the Swedish Heart-Lung Foundation and Skåne University Hospital. 


\section{Disclosure}

The authors report no conflict of interest in this work.

\section{References}

1. American Thoracic Society/European Respiratory Society Statement. Standards for the diagnosis and management of individuals with alpha-1 antitrypsin deficiency. Am J Respir Crit Care Med. 2003;168: 818-900.

2. Stoller JK, Aboussouan LS. A review of $\alpha 1$-antitrypsin deficiency. Am J Respir Crit Care Med. 2012;185(3):246-259.

3. Gettins PG, Structure S. Mechanism, and function. Chem Rev. 2002; 102:4751-4804.

4. Laurell CB, Eriksson S. The electrophoretic alpha-1-globulin pattern of serum in alpha-1-antitrypsin deficiency. Scand J Clin Lab Invest. 1963; 15:132-140.

5. Gooptu B, Dickens JA, Lomas DA. The molecular and cellular pathology of $\alpha_{1}$-antitrypsin deficiency. Trends. 2014;20:116-127.

6. Mahadeva R, Atkinson C, Li Z, et al. Polymers of Z alpha1-antitrypsin co-localize with neutrophils in emphysematous alveoli and are chemotactic in vivo. Am J Pathol. 2005;166(2):377-386.

7. Curiel DT, Chytil A, Courtney M, Crystal RG. Serum alpha 1-antitrypsin deficiency associated with the common S-type (Glu264-Val) mutation results from intracellular degradation of alpha 1-antitrypsin prior to secretion. J Biol Chem. 1989;264(18):10477-10486.

8. Nakano S, Nakahira J, Sawai T, et al. Perioperative evaluation of respiratory impedance using the forced oscillation technique: a prospective observational study. BMC Anesthesiol. 2015;16(1):32.

9. Shirai T, Kurosawa H. Clinical application of the forced oscillation technique. Intern Med. 2016;55(6):559-566.

10. Brashier B, Salvi S. Measuring lung function using sound waves: role of the forced oscillation technique and impulse oscillometry system. Breathe. 2015;11(1):57-65.

11. Frantz S, Nihlén U, Dencker M, Engström G, Löfdahl CG, Wollmer P. Impulse oscillometry may be of value in detecting early manifestations of COPD. Respir Med. 2012;106(8):1116-1123.

12. Stolk J, Stoel BC. Lung densitometry to assess progression of emphysema in chronic obstructive pulmonary disease: time to apply in the clinic? Am J Respir Crit Care Med. 2011;183(12):1578-1580.

13. Ju J, Li R, Gu S, et al. Impact of emphysema heterogeneity on pulmonary function. PLoS One. 2014;9(11):e113320.

14. Edgar RG, Patel M, Bayliss S, Crossley D, Sapey E, Turner AM. Treatment of lung disease in alpha-1 antitrypsin deficiency: a systematic review. Int J Chron Obstruct Pulmon Dis. 2017;12:1295-1308.
15. Sveger T. Liver disease in alpha1-antitrypsin deficiency detected by screening of 200,000 infants. N Engl J Med. 1976;294(24):1316-1321.

16. Miller MR, Hankinson J, Brusasco V, et al. ATS/ERS Task force standardization of lung function testing. Standardization of spirometry. Eur Respir J. 2005;26:319-338.

17. Culver BH, Graham BL, Coates AL, et al; ATS Committee on Proficiency Standards for Pulmonary Function Laboratories. Recommendations for a standardized pulmonary function report. An Official American Thoracic Society Technical Statement. Am J Respir Crit Care Med. 2017;196(11):1463-1472.

18. Quanjer PH. Standardized lung function testing. Report of the working party on standardization of lung function tests. European Community for Coal and Steel. Bull Eur Physiopathol Respir. 1983;19(Suppl 16): $1-95$.

19. Oostveen E, Macleod D, Lorino H, et al; ERS Task Force on Respiratory Impedance Measurements. The forced oscillation technique in clinical practice: methodology, recommendations and future developments. Eur Respir J. 2003;22(6):1026-1041.

20. Piitulainen E, Montero LC, Nystedt-Düzakin M, et al. Lung function and CT densitometry in subjects with alpha-1-antitrypsin deficiency and healthy controls at 35 years of age. COPD. 2015;12(2):162-167.

21. Stolk J, Versteegh MIM, Montenij LJ, et al. Densitometry for assessment of effect of lung volume reduction surgery for emphysema. Eur Respir J. 2007;29(6):1138-1143.

22. Piitulainen E, Mostafavi B, Tanash HA. Health status of the Swedish alpha 1-antytrypsin-deficient cohort identified by neonatal screening, at the age of 37-40 years. Int J Chron Obstr Pulmon Dis. 2017;12:1-6.

23. Tanash HA, Ekström M, Rönmark E, Lindberg A, Piitulainen E. Survival in individuals with severe alpha 1-antitrypsin deficiency (PiZZ) in comparison to a general population with known smoking habits. Eur Respir J. 2017;50(3):1700198.

24. Sandhaus RA, Turino G, Brantly ML, et al. The diagnosis and management of alpha-1 antitrypsin deficiency in the adult. Chronic Obstr Pulm Dis. 2016;3(3):668-682.

25. Bernspång E, Wollmer $\mathrm{P}$, Sveger T, Piitulainen E. Lung function in 30-year-old alpha-1-antitrypsin-deficient individuals. Respir Med. 2009;103(6):861-865.

26. Suzuki M, Sze MA, Campbell JD, et al. The cellular and molecular determinants of emphysematous destruction in COPD. Sci Rep. 2017;7(1):9562. 


\section{Supplementary material}

\section{Participants questionnaire}

1. Number of children:

How many of them have been tested for alpha-1-antitrypsin deficiency?

$\square$ Do not know

\section{Occupation:}
Are you currently employed
$\square$ Yes
$\square$ No
If No, give the reason.

Current occupation:

From year:

Former occupations:

\begin{tabular}{|c|c|c|}
\hline From year & To year & Occupation \\
\hline From year & To year & Occupation \\
\hline From year & To year & Occupation \\
\hline
\end{tabular}

3. Workplace environment

A. Have you ever regularly been exposed to dust, fumes and gas for at least three months?

$\square$ Yes $\square$ No $\square$ Do not know If Yes, for how many years:

\section{Smoking habits}
A. Have you ever regularly smoked?
$\square$ Yes
$\square$ No
If Yes:
$\square$ Cigarettes?
If Yes, when did you start?
Age: ..year
$\square$ Pipe?
$\square$ Cigars?

B. Have you stopped smoking?

$\square$ Yes

$\square$ No If Yes, when did you stop?

Age: ..year

C. Your current smoking habits

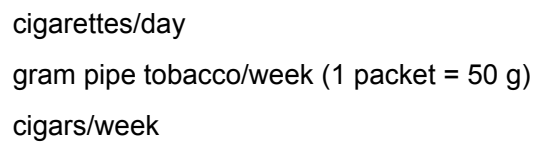

D. During the time you smoked, how much did you smoke on average?

cigarettes/day

gram pipe tobacco/week $(1$ packet $=50 \mathrm{~g})$

cigars/week

5. State of health

A. Physical activities:

$\checkmark$ I practice (name the sport you practice) .at least........ Times/week

口 I exercise (name the exercise, eg, long walk) at least. Times/week

$\checkmark$ I do not practice or exercise

B. Estimate your general state of health by marking an $X$ on the line below:

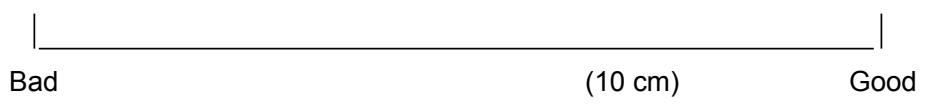

Figure SI (Continued) 
C. How often have you had pneumonia?

D. Did you have daily cough for at least three consecutive months a year?

If yes, for how many years?
Number of times: $\square$ Do not know
E. Does your chest ever sound wheezy or whistle?
$\square$ Yes $\square$ No

If yes, for how many years?

F. Estimate your exertion capacity when walking $100 \mathrm{~m}$ on level ground by setting an $X$ on the line below:

Low $\quad(10 \mathrm{~cm}) \quad$ High

\section{G. Estimate your breathlessness by setting $X$ on the number corresponding to the description:}

\begin{tabular}{|l|l|}
\hline 0 & No breathlessness \\
\hline 1 & I only get breathless with strenuous exercise \\
\hline 2 & I get short of breath when hurrying on level ground or walking up a slight hill \\
\hline 3 & On level ground, I walk slower than people of the same age because of breathlessness \\
\hline 4 & I stop for breath after walking about 100 yards or after a few minutes on level ground when walking at my own pace \\
\hline 5 & I am too breathless to leave the house or I am breathless when dressing \\
\hline
\end{tabular}

\section{H. If you chose alternative $2-5$,}

How long have you had trouble with breathlessness? Number of years.

Thank you for your participation

Figure SI Cohort and control group questionnaire.

Notes: A Swedish version of this questionnaire was used for 26, 30, and 34-year follow-ups and the current follow-up, and was translated (by a professional translator) to English at the 30-year follow-up. At that follow-up we removed a question and added two new ones.

\section{Publish your work in this journal}

The International Journal of COPD is an international, peer-reviewed journal of therapeutics and pharmacology focusing on concise rapid reporting of clinical studies and reviews in COPD. Special focus is given to the pathophysiological processes underlying the disease, intervention programs, patient focused education, and self management protocols.

\section{Dovepress}

This journal is indexed on PubMed Central, MedLine and CAS. The manuscript management system is completely online and includes a very quick and fair peer-review system, which is all easy to use. Visit $\mathrm{http} / / / \mathrm{www}$.dovepress.com/testimonials.php to read real quotes from published authors. 